\title{
Revision of the myrmecophilous diapriid genus Bruchopria Kieffer (Hymenoptera, Proctotrupoidea, Diapriidae)
}

\author{
Marta S. Loiácono ${ }^{1}$ \\ Cecilia B. Margaría ${ }^{1}$ \\ Estela Quirán ${ }^{2}$ \\ Bárbara Corró Molas ${ }^{2}$
}

\begin{abstract}
A redescription of the genus Bruchopria and its two species, B. hexatoma Kieffer (female and male) and $B$. pentatoma Kieffer (male only) is presented. New record for B. hexatoma from Argentina is provided. Some aspects of diapriid biology with emphasis on their myrmecophilic evidence and association with ants are discussed. Scanning photographs of morphological structures are included.
\end{abstract}

KeYwords. Bruchopria; Diapriidae; Formicidae; Hymenoptera; myrmecophilous.

\section{INTRODUCTION}

The main objective of this paper is to study the species of the genus Bruchopria Kieffer associated with ants in Argentina and Brazil. Bruchopria includes two species, B. pentatoma Kieffer, 1821 and B. hexatoma Kieffer, 1821, both from Argentina, the latter also recorded from Brazil.

Borgmeier (1939) had included Bruchopria in the tribe Diapriini, close to Solenopsia Wasmann. In the present paper we transfer the genus to the tribe Spilomicrini, based on the following character states: 13 segmented antenna of male and female, subcostalis vein separated from wing edge along its length, and ending distally in a short marginalis vein; stigmalis vein well developed. According to MASNER (1991), Spilomicrini is characterized by a single synapomorphy: 13 antennomeres for both sexes, and includes several genera of worldwide distribution, with greatest diversity in the tropics and the Southern hemisphere. Some of the included genera need revision.

Within Spilomicrini, Bruchopria seems to be closer to Entomacis Foerster, but differs for the absence of fovea of scutellum and by the different apex of the wing.

Several diapriid-species are associated with ants, being highly adapted to their host habits. Dealation is frequent among this myrmecophilous species, and absence of wings due to dealation can mislead indentifications, and have caused several taxonomic problems. This is the case of Bruchopria species.

KIEFFER (1921), in the original genus description, highlights clearly "aile nule" and "ocellus nule". However, the material studied herein shows that ocelli, tegulae, and stumps of wings are present. Moreover, BorgmeIER (1939) described the male of $B$. hexatoma and remarked "propodeum keel absent", but we have seen that the propodeum keel is indeed present.

The main objective of this paper is to redescribe and illustrate Bruchopria, to present evidences of its myrmecophilic habits, discussing the degree of their association with formicids.

\section{MATERIAL AND METHODS}

Diapriid specimens examined in this study are deposited in the Museo de La Plata (MLP). Measurements were taken using a stereoscopic microscope with a micrometric eyepiece. Observations were also made with a Scanning Electron Microscope (SEM) Jeol-JSM-T100 at the Museo de La Plata operating at $15 \mathrm{KV}$.

Valuable myrmecophilous Diapriidae resulting from C. Bruch's exploration of formicid associates in Argentina were available for study to us. This material includes representatives of the two known species of Bruchopria Kieffer: B. pentatoma Kieffer and $B$. hexatoma Kieffer, from the type localities.

Abbreviations used in the descriptions: POL (postocellar line), distance between the lateral ocelli; LOL (lateral ocellar

\footnotetext{
1. Departamento Científico de Entomología, Facultad de Ciencias Naturales y Museo, UNLP, Paseo del Bosque s/n, 1900, La Plata, Buenos Aires, Argentina. E-mail: loiacono@museo.fcnym.unlp.edu.ar.

2. Facultad de Ciencias Exactas y Naturales, UNLPam, Uruguay 151, 6300 Santa Rosa, La Pampa, Argentina.
} 

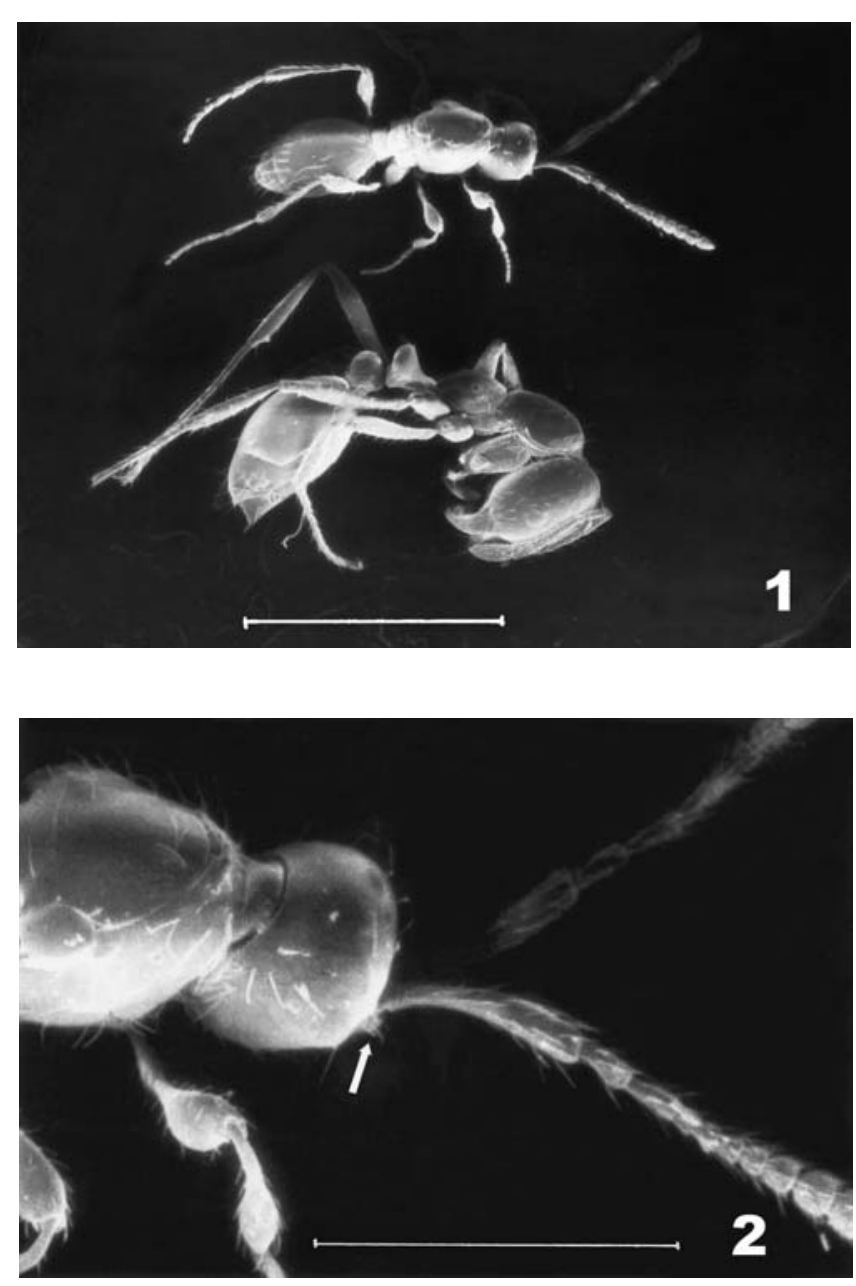

Figs. 1-2. 1, Bruchopria hexatoma. Female (upper specimen) with the host ant worker Solenopsis richteri; scale $=2 \mathrm{~mm} ; \mathbf{2}, B$. hexatoma, female, head, mesosoma in lateral view, and legs. Arrow indicates antennal shelf; scale $=0,5 \mathrm{~mm}$.

line), distance from the median and lateral ocellus; OOL (ocularocellar line), distance from outer margin of lateral ocellus to compound eye; $\mathrm{A}_{\mathrm{n},}$ antennomere number, and antennomeres relative proportions: maximum length and width; $\mathrm{T}_{2}$, metasomatic tergite II.

\section{Bruchopria Kieffer, 1921}

(Figs. 1-8)

Bruchopria Kieffer, 1921: 38; Borgmeier, 1939: 543 (bibliography; diagnosis); Muesebeck \& Walkley, 1956: 337 (citation of type species); De Santis, 1967: 220 (catalog of species from Argentina); 1980: 308 (catalog of species from Brazil).

Type species: Bruchopria pentatoma Kieffer 1921, by original designation.

Diagnosis. Female and male antennae 13-segmented. $\mathrm{A}_{4}$ of male excavated. Pronotal collar distinctly prominent. Notauli absent. Scutellum without fovea. Macropterous; fore wings with submarginal vein slightly exceeding basal $1 / 3$ and metapleura, propodeum and petiole with short adpressed pubescence.

Redescription. Female(Fig. 1, above). Body chestnut brown with sutures and edges darker, tegulae and appendages light; predominantly smooth and shiny, with scattered long semidecumbent setae.

Head (Fig. 2) subglobose, clothed with long hairs, fine longitudinal rugosity lateral and anteriorly on antennal shelf; antennal shelf slightly prominent; ocelli small (Fig. 2), malar space 2 times longer than eye, OOL at least 1.5 times as wide as POL; compound eyes small with raspberry ommatidia and pilosity, malar space 2 times as long as the diameter of the eye, mouth very narrow; mandibules bidentate, lower tooth sharp and much longer than upper tooth; palpi short with formula 32; hypostomal carinae fine, clypeus not delimited above; antennae with moderate to indistinct 5-6 segmented club (Fig. 3); $A_{3}$ elongate, $A_{4}-A_{7}$ subequal in length, $A_{8}-A_{13}$ globuliform, scape entirely with fine reticulation, flagellum clothed with rather long bushy dense pilosity.

Mesosoma (Fig. 5). Pronotum distinctly prominent in dorsal view; pronotal collar slightly hairy. Mesoscutum distinctly wider than long, with setae in two submedian rows. Scutellar shield subquadrangular and smooth. Metanotum with two longitudinal keels and dense pilosity, median keel of propodeum reduced (Fig. 5); hairs on propodeum minute and very dense. Propleura and mesopleura smooth and shiny, with scattered setae. Fore wing long (Fig. 6), submarginal vein tubular, closely parallel with the frontal margin of wing; basal vein absent; marginal, postmarginal and stigmal as in Fig. 6 (below); hind wing narrow,

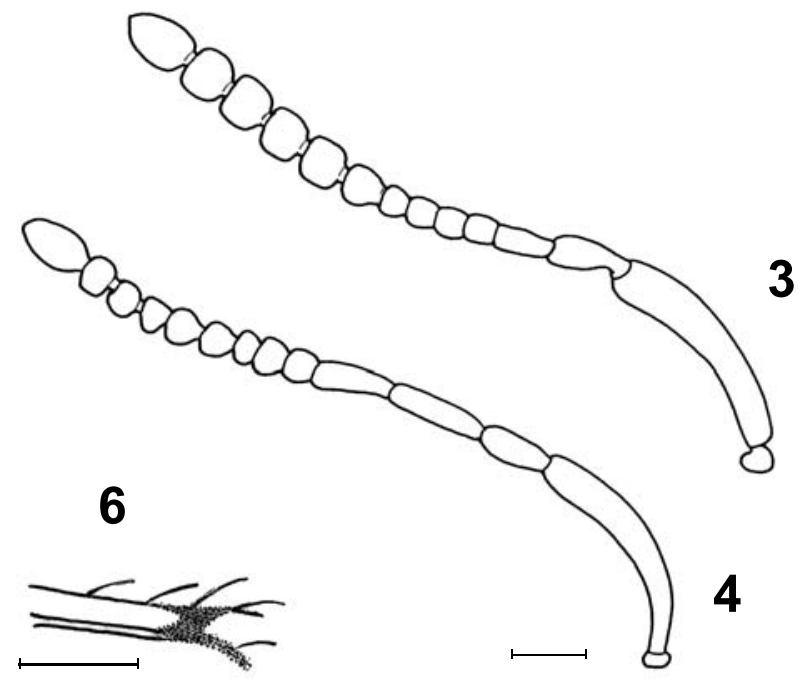

Figs. 3-4, 6. Bruchopria hexatoma. 3, female antenna; 4, male antenna; scale $=0,1 \mathrm{~mm}$. 6, female: part of fore wing; scale $=0,1 \mathrm{~mm}$. 


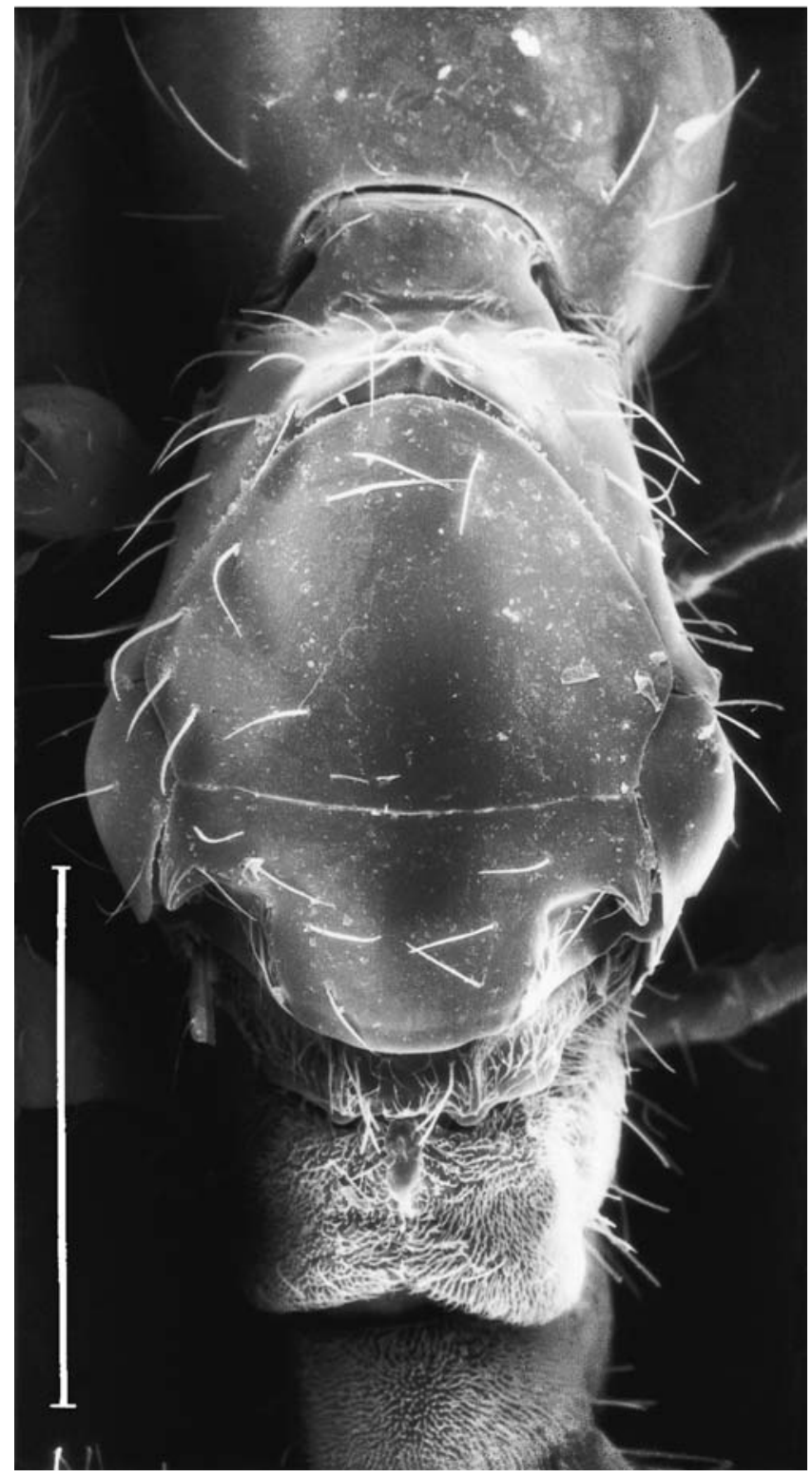

Fig. 5. Bruchopria hexatoma, female: mesosoma and petiole in dorsal view; scale $=0,5 \mathrm{~mm}$.

with submarginal vein reduced to a rudiment at base. Legs moderately robust, femora and tibia distally incrassate, tarsi compressed (Figs. 1-2).

Metasoma. Petiole (Fig. 5) with short dense pilosity, wider than long, anterior margin of $\mathrm{T}_{2}$ entire, $\mathrm{T}_{2}$ and following tergites with longitudinal lines of semidecumbent setae.

Male. Differs from female only in the following character states: eye considerably larger than in the female; antennomeres $\mathrm{A}_{3}$ and $\mathrm{A}_{4}$ modified and long (Fig. 4), and $\mathrm{A}_{4}$ excavated.

Biology. Biological data available indicate that the two species of Bruchopria are associated with ants of the genera Solenopsis Westwood and Acromyrmex Mayr. Bruchopria hexatoma has been reported by KIEFFER (1921) in association with "S. saevissima var. richteri Forel and Acromyrmex lundi
(Guérin)" in Argentina; BorgmeIER (1939) also mentioned this species as a guest of "S. saevissima var. richteri (probably subsp. moelleri Forel)", in Brazil. On the other hand, $B$. pentatoma has been listed by KIEFFER (1921) as a guest of "S $\underline{\text { S }}$ saevissima var. richteri" in Argentina, and HöLlDOBLER \& WiLsOn (1990) mentioned specimens of genus Bruchopria, as Solenopsis guest.

Alated and dealated individuals of Bruchopria species are present in the material studied. The action of dealation has not been observed. The apices of the wing stumps (Fig. 7) of all individuals examined were regular suggesting that the wings are bitten or torn off close to the tegulae (Fig. 5). The fact that specimens are dealated allows them to move into the mound galleries and chambers. The brood chambers (Fig. 8) are difficult for parasites to penetrate, because they are fiercely defended by ants.

Distribution. Argentina (Buenos Aires, Córdoba and Misiones) and Brazil (Santa Catarina). The diapriids studied in this paper have been found mainly associated with Solenopsis richteri. The geographical distribution of Bruchopria species is partially coincident with the ants' distribution: Argentina, Brazil, Uruguay and Paraguay, and United States (KeMPF 1972; BRANDÃo 1991).

Bruchopria hexatoma Kieffer, 1921

(Figs. 1-8)

Bruchopria hexatoma Kieffer, 1921: 39 (female); Borgmeier, 1939: 543 (bibliography; description of male)

Female. Body (Fig. 1). Length (excluding antennae) about 1.9-2.2 mm, color chestnut brown with sutures and edges darker, tegulae and appendages light

Head (Fig. 2) in dorsal view globose (37:30), with pilosity of temples rather sparse; eyes shorter than temples and pilous; ocelli close together POL: LOL:OOL $=7: 4: 11$; head in lateral view slightly longer than wide (35:29); antenna (Fig. 3) with segments in proportions 32:6, 11:4, 9:3, 4:3, 4:3, 4:4, 4:4, 5:5, 6:6, 6:7, 6:7, 6:7, 10:6.

Mesosoma. Pronotum elevated in dorsal view. Mesoscutum distinctly wider than long (35:38), with setae placed as in Fig. 5; scutellar shield subquadrangular and smooth, median keel of propodeum reduced (Fig. 5). Fore wing (Fig. 6) with marginal vein cilia about $1 / 10$ of the wing width, sparsely hairy on disk in the proximal third; femora and tibia distal and gradually incrassate (Fig. 2). Petiole (19:10) with dense short pilosity; body of metasoma about 1.75 times as long as wide; $\mathrm{T}_{2}$ (50:40).

Male. Differs from female only in the following character states: length $2.3 \mathrm{~mm}$, colour slightly darker than female, eyes somewhat larger; ocelli more conspicuous than in female; antenna (Fig. 6) with segments in proportions 33:7, 11:5, 15:5, 12:5, 4:6, 4:6, 5:6, 6:7, 6:7, 6:7, 6:7, 6:7, 11:7; A slightly excavated.

Biology. This species is host of Solenopsis richteri and Acromyrmex lundi. 


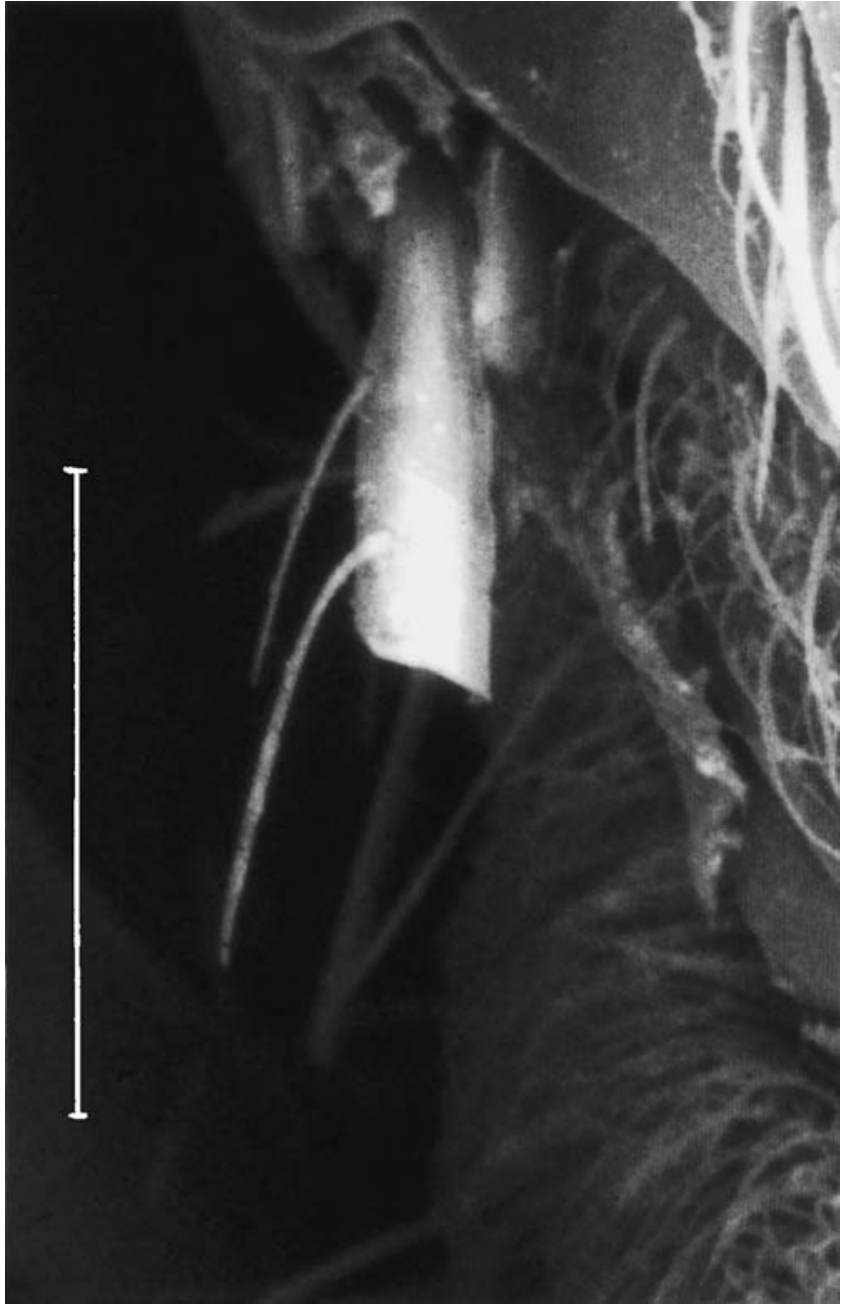

Fig. 7. Bruchopria hexatoma, wing stump; scale $=0.1 \mathrm{~mm}$.

Variability. Very little variation has been noticed among individuals, except for the darker coloration of the female from Misiones.

Distribution. ARGENTINA: Misiones, Córdoba and Buenos Aires. Pastoreo Grande is the first record from Misiones.

Material examined. ARGENTINA. Misiones. Pastoreo Grande, 1 female dealated, 9.VII.1932, A. Ogloblin (MLP). Córdoba, 1 female dealated, XII.1920, C. Bruch (MLP). Buenos Aires. Without locality, 1 male dealated, 9.VII.1923, C. Bruch (MLP); Olivos, 4 females dealated, without date, C. Bruch (MLP); La Plata, 1 female, 25.V.1920, C. Bruch (MLP). Data of collection, lacking. Microscopic slide: antenna of male; antenna, fore wing and leg of female (Ogloblin's collection).

Remarks. The specimens from the provinces of Córdoba and Buenos Aires are dealated, with remains of wings (Fig. 7), and most of them are accompanied by the host ants (Fig. 1). Unfortunately, the types of the species described by Kieffer have become widely scattered or lost (MASNER 1965). Bruch sent to Kieffer part of the same series of material to identify ( $D E$ SANTIS, personal comunication).

\section{Bruchopria pentatoma Kieffer, 1921}

Bruchopria pentatoma Kieffer, 1921: 38 (male, female).

Since we have found no females specimens of B. pentatoma $a_{2}$ in the studied material we only compare it with males of $B$. hexatoma.

Male. Similar to $B$. hexatoma, differing in the length of the body $(1.8 \mathrm{~mm})$ and in the length ratios of the first four antennomeres $\left(\mathrm{A}_{1-} \mathrm{A}_{4}\right)$ which are: 16:3:7:5.

Biology. This species is associated with Solenopsis richteri.

Distribution. ARGENTINA: Córdoba.

Material examined. 1 male syntype dealated, MLP $\mathrm{N}^{\circ} 1581$, Argentina, Córdoba, Alta Gracia; 1/8-IV-1920, C. Bruch col.

Remarks. According to Kieffer's description, females of both species, $B$. pentatoma and $B$. hexatoma, are distinguished by the number of club antennomeres, five and six respectively. Unfortunately, the unique female type is not available.

\section{DISCUSSION}

Species of Bruchopria show a number of features correlated with myrmecophilous habits in diapriids, such as reduced eye size, integument similar to ants', and dealation. These features are usually more pronounced in the female. According to WING (1951) such similarity between ant and guest integument, favors their mimicry, as the ants are specialists in the perception of textures. HölLDOBLER \& WILSON (1990) also remark that very special adaptations are needed for myrmecophiles to exploit this new ecological niche. Adaptations mentioned above allow

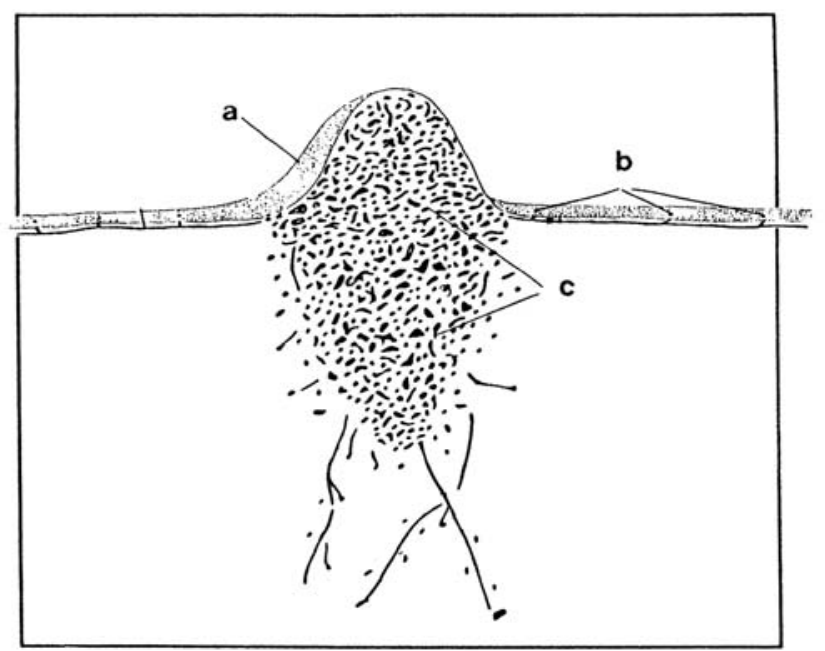

Fig. 8. The fire ant mound (modified from VINSON \& SORENSEN 1986): a, mound; b, foraging tunnel entrance/exits; c. mound galleries and chambers. 
us to consider that these species could be included within the group of integrated myrmecophiles, according to Kistner's classification (KISTNER 1979). These species are incorporated into their hosts' social lives, by behavioural modification of both parties.

The presence of tegulae with normal development and wing stumps observed under SEM, demonstrate that the apterism has a secondary origin, caused by the autotomy or by bites of the host ants. The fact that specimens of Bruchopria are found accompanied by formicids, supports MASNER's observations (1976) that during the dealated phase the wasps are closely associated with their hosts.

We suspect that species of the genus Bruchopria behave as parasitoids of mature larvae of ants, as others diapriids whose life cycles are known. This point of view is strengthened by the report of the parasitoidism of the diapriids Gymnopria lucens Loiácono and G. pampeana Loiácono, in mature larvae of the ant species Acromyrmex ambiguus Emery and $A$. lobicornis Emery (Myrmicinae), respectively (LoIÁCONO 1987; LOIÁCONO et al. 2000).

Acknowledgements. We would like to thank Dra. A. Lanteri for the critical reading of the manuscript, and Dr. J. Briano for bibliographic references. We express our appreciation to the anonymous referees for their useful suggestions to improve this manuscript.

\section{REFERENCES}

Borgmeier, T. 1939. Sobre alguns Diapriideos myrmecophilos, principalmente do Brasil (Hym. Diapriidae). Revista de Entomologia 10(3):530-545.

Brandẽo, C. R. F. 1991. Adendos do Catálogo abreviado das formigas da Região Neotropical (Hymenoptera: Formicidae). Revista Brasileira de Entomologia 35(2):319-412.

De Santis, L. 1967. Catálogo de los Himenópteros Argentinos de la serie parasítica, incluyendo Bethyloidea. Comisión de
Investigaciones Científicas de la provincia de Buenos Aires, 337 p. De Santis, L. 1980. Catálogo de los Himenópteros Brasileños de la Serie parasítica, incluyendo Bethyloidea. Curitiba, Universidade Federal do Paraná, 395 p.

Hölldobler, B. and E. O. Wilson. 1990. The ants. Cambridge, Harvard University Press, $732 \mathrm{p}$

KempF, W. W. 1972. Catálogo abreviado das Formigas da Região Neotropical (Hym. Formicidae) Studia Entomologica 15(1-4): 3344.

KiefFer, J. J. 1921. Proctotrypides hôtes des fourmis en Argentine. Anales de la Sociedad Científica Argentina 91:36-41.

KISTNER, 1979. Revision of the myrmecophilous tribe Deremini III: The remainder of the genera with notes on behavior, ultraestructure, glands and phylogeny (Coleoptera: Staphyliinidae). Sociobiology 3(3): 141-391.

LoiÁcono, M. S. 1987. Un nuevo diáprido (Hymenoptera) parasitoide de larvas de Acromyrmex ambiguus (Emery) en el Uruguay. Revista de la Sociedad Entomológica Argentina 44(2):129-136.

Loiácono, M. S.; C. B. Margaría; E. Quirán \& B. Corró Molas. 2000. Diápridos (Hymenoptera) parasitoides de larvas de la hormiga cortadora Acromyrmex lobicornis Emery (Hymenoptera: Formicidae) en Argentina. Revista de la Sociedad Entomológica Argentina 59(1-4):7-15.

Masner, L. 1965. The types of Proctotrupoidea (Hymenoptera) in the British Museum (Nat. Hist.) and the Hope Department of Entomology (Oxford). Bulletin of the British Museum of Natural History Supplements 1:1-154.

MAsner, L. 1976. Notes on the ecitophilous diapriid genus Mimopria Holmgren (Hymenoptera: Proctotrupoidea, Diapriidae). The Canadian Entomologist 108:123-126.

Masner, L. 1991. Revision of Spilomicrus Westwood in America North of Mexico (Hymenoptera: Proctotrupoidea, Diapriidae). The Canadian Entomologist 123:107-177.

Muesebeck, C. F. W. \& L. M. Walkey. 1956. Type species of the genera and subgenera of parasitic wasps comprising the superfamily Proctotrupoidea (order Hymenoptera). Proceedings of the United States Natural History Museum 105:319-419.

Vinson, S. B. \& A. A. SORENSEN. 1986. Imported fire ants: life history and impact. Texas, Department of Agriculture, $28 \mathrm{p}$.

WING, M. W. 1951. A new genus and species of myrmecophilous Diapriidae with taxonomic and biological notes on related forms (Hymenoptera). Transactions of the Royal Entomological Society of London 102:195-210. 